\title{
PENENTUAN LINTASAN TERPENDEK DARI FMIPA KE REKTORAT DAN FAKULTAS LAIN DI UNSRAT MANADO MENGGUNAKAN ALGORITMA DJIKSTRA
}

\author{
Deiby T. Salaki ${ }^{1)}$ \\ ${ }^{1)}$ Program Studi Matematika FMIPA Universitas Sam Ratulangi, Manado 95115
}

\begin{abstract}
ABSTRAK
Universitas Sam Ratulangi Manado adalah salah satu perguruan tinggi di Sulawesi Utara yang terdiri atas 11 fakultas dan satu gedung rektorat. Setiap fakultas dan rektorat terhubung dengan fasilitas jalan raya. Secara matematis kondisi seperti ini dapat direpresentasikan sebagai sebuah graf yang bisa diterapkan untuk mencari lintasan terpendek. Pada penelitian ini akan dicari lintasan terpendek dari FMIPA ke rektorat dan fakultas lainnya. Dengan menggunakan algoritma Djikstra, lintasan terpendek dari FMIPA diperoleh dengan memilih minimum lokal atau akses dengan jarak terdekat dari setiap lokasi yang kemudian digabungkan menjadi sebuah kumpulan lintasan dari satu lokasi ke lokasi lainnya dengan jarak terpendek.
\end{abstract}

Kata Kunci: algoritma djikstra, graf, masalah lintasan terpendek

\section{DETERMINATION OF SHORTEST PATH FROM FMIPA TO RECTORATE AND OTHER FACULTIES AT SAM RATULANGI UNIVERSITY USING DJIKSTRA ALGORITHM}

\begin{abstract}
Sam Ratulangi University is one of the colleges in North Sulawesi consisting of 11 faculties and one rectorate building. Every faculty and rectorate connected by highway facilities. Mathemathically this condition can be represented as an undirected weighted graph that can be applied to find the shortest path. By using the Djikstra algorithm, the shortest paths are obtained by setting the FMIPA as the initial vertex and then select the local minimum or access to the closest distance from each location, then combined the collection of path from one location to another with the shortest distance.
\end{abstract}

Keywords: djikstra algorithm, graph, shortest path problem

\section{PENDAHULUAN}

Universitas Sam Ratulangi (Unsrat) Manado merupakan salah satu perguruan tinggi di Sulawesi Utara dengan luas area sekitar $1.320 .816 \mathrm{~m}^{2}$. Unsrat terdiri atas 11 fakultas dan satu gedung rektorat yang letaknya relatif terpisah satu dengan yang lain. Setiap fakultas dan rektorat terhubung dengan fasilitas jalan raya, yang juga merupakan sarana untuk mengakses antara satu fakultas dengan fakultas lainnya. Secara matematis kondisi seperti ini dapat direpresentasikan sebagai sebuah graf. Graf adalah pasangan himpunan vertex/simpul dan edges/sisi, dimana setiap sisi berhubungan dengan satu atau dua buah simpul. Dalam graf dapat merepresentasikan jalan dan simpul dapat merepresentasikan tempat atau lokasi.

Salah satu masalah umum yang dapat diselesaikan dengan menggunakan teori graf yaitu Masalah Lintasan Terpendek (Shortest Path Problem/SPP) yang mencari lintasan dengan jumlah bobot paling minimum. Algoritma Djikstra merupakan salah satu algoritma untuk menyelesaikan masalah ini. 
Penelitian ini ditujukan untuk membuat lintasan terpendek yang dapat dilalui kendaraan roda empat dari FMIPA ke fakultas lainnya di Unsrat dengan menggunakan Algoritma Djikstra.

\section{TINJAUAN PUSTAKA}

\section{Teori Graf}

Suatu Graf $G=(V, E)$ didefinisikan sebagai pasangan himpunan sisi dan simpul dengan $V(G)=$ Himpunan simpul $\left\{v_{1}, v_{2}, \ldots\right.$, $\left.v_{n}\right\}$ dan $E(G)=$ Himpunan sisi $\left\{e_{1}, e_{2}, \ldots, e_{n}\right\}$.

Setiap sisi berhubungan dengan satu atau dua simpul. Dua buah simpul dikatakan berhubungan atau bertetangga (adjacent) jika ada sisi yang menghubungkan keduanya. Berdasarkan orientasi yang ada pada sisinya, graf dapat dikelompokkan menjadi dua yaitu: Graf berarah (direct graf) yaitu graf yang setiap sisinya diberikan arah sehingga untuk dua simpul $v_{i}$ dan $v_{j}$, maka $\left(v_{i}, v_{j}\right) \neq\left(v_{j}, v_{i}\right)$ dan graf tak berarah (undirect graf) yaitu graf yang sisinya tidak mengandung arah sehingga untuk dua simpul $v_{i}$ dan $v_{j}$, maka $\left(v_{i}, v_{j}\right)=$ $\left(v_{j}, v_{i}\right)$. Selain itu juga dikenal graf berbobot yaitu graf yang sisinya memiliki bobot atau (Ahuja et al, 1993)..

\section{Matriks Ketetanggaan (adjacency matrix)}

Misalkan sebuah graf $G=(V, E)$ dengan jumlah simpul $n$. Matriks ketetanggaan $G$ adalah matriks bujursangkar dengan ukuran $n \times n$. atau $M=\left[m_{i j}\right]$, dengan $m_{i j}=1$ jika simpul $i$ dan $j$ bertetangga, sebaliknya $m_{i j}=0$ jika simpul $i$ dan $j$ tidak bertetangga (Munir, 2005).

\section{Masalah Lintasan Terpendek (SPP)}

SPP adalah suatu persoalan untuk mencari lintasan antara dua atau lebih simpul pada graf berbobot yang gabungan bobot sisi graf yang dilalui berjumlah paling minimum. Persoalan ini juga merupakan suatu persoalan optimasi yang menggunakan graf berbobot, dimana bobot dapat menyatakan jarak antar kota, waktu pengiriman pesan, ongkos pembangunan, dan sebagainya (Pradana, 2009).

\section{Algoritma Djikstra}

Algoritma Djikstra merupakan salah satu metode untuk mencari lintasa- -....endek dari sebuah simpul ke semua sim linnya dalam graf yang hanya memiliki bobot positif. Secara formal, masalah lintasan terpendek semua pasangan simpul adalah untuk mencari lintasan terpendek di antara semua pasang simpul $v_{i}, v_{i} \in V$ sedemikian sehingga $i \neq j$ (Sarwoko, 2003)

Dalam mencari lintasan terpendek dari suatu simpul ke semua pasangan simpul algoritma Djikstra melalui sejumlah langkah yang menggunakan prinsip greedy. Prinsip greedy pada algoritma Djikstra menyatakan bahwa pada setiap langkah kita memilih sisi yang berbobot minimum dan memasukkannya dalam himpunan solusi (Munir, 2005).

Selain matriks ketetanggaan $M$, algoritma ini menggunakan tabel $S=\left[s_{i}\right]$, dengan $s_{i}=1$, jika simpul $i$ termasuk ke dalam lintasan terpendek dan sebaliknya $s_{i}=$ 0 , jika simpul $i$ tidak termasuk ke dalam lintasan terpendek dan juga tabel $D=\left[d_{i}\right]$, dengan $d_{i}=$ panjang lintasan dari simpul awal $a$ ke simpul $i$

Langkah-langkah penentuan lintasan terpendek dari graf $G$ dengan $n$-buah simpul dengan simpul awal $a$ menggunakan algoritma Djikstra adalah sebagai berikut:

1. Langkah 0 (inisialisasi): $s_{i}=0$ dan $d_{i}=$ $m_{a i}$ untuk $i=1,2, \ldots, n$

2. Langkah 1: isi $s_{a}$ dengan 1 dan isi $d_{a}$ dengan $\infty$.

3. Langkah 2: untuk setiap $s_{i}=0$ dengan $i=$ $1,2, \ldots, n$, pilih $d_{j}=\min \left\{d_{1}, d_{2}, \ldots, d_{n}\right\}$ lalu isi $s_{j}$ dengan 1 dan perbarui $d_{i}$, dengan: $d_{i}$ (baru) $=\min \left\{d_{i}\right.$ (lama),$d_{j}+m_{j i}$ \}. Pada lintasan, tambahkan simpul $j$ sebagai simpul terpilih untuk lintasan selanjutnya.

4. Langkah 3: mengulangi langkah 2 sampai $s_{j}=1$, untuk $j=1,2, \ldots, n$

5. Membuat himpunan simpul berdasarkan urutan yang diperoleh yang merupakan lintasan terpendek dengan bobot $d_{i}$ (Munir, 2009)

\section{METODOLOGI PENELITIAN}

Data yang digunakan dalam penelitian ini yaitu berupa jarak antar fakultas dan rektorat yang diperoleh berdasarkan pengukuran pada peta kampus Universitas Sam Ratulangi Manado (Google Map). Peta 
kemudian direpresentasikan dalam sebuah graf lalu dibuat matriks ketetanggaannya dan selanjutnya menentukan lintasan terpendek dari FMIPA ke fakultas lain dan gedung rektorat dengan menggunakan algoritma Djikstra. Perhitungan dilakukan dengan bantuan software Pascal.

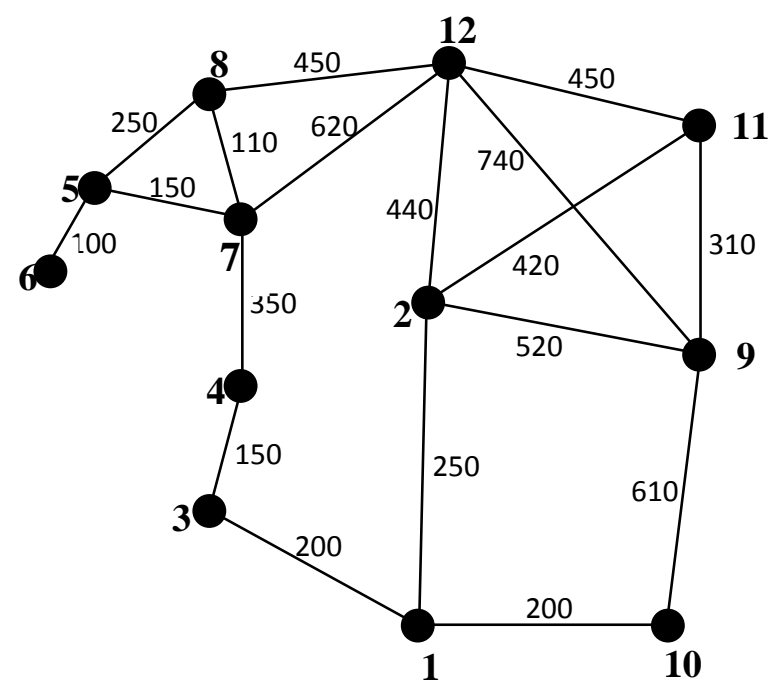

Gambar 1. Graf Universitas Sam Ratulangi Manado

\section{HASIL DAN PEMBAHASAN}

Berdasarkan peta Unsrat dapat dibuat graf seperti pada gambar 1. Gambar 1 merupakan graf berbobot tak berarah yang terdiri atas 12 simpul dimana simpul 1 mewakili kantor rektorat dan simpul 2 sampai 12 berturut-turut mewakili Fakultas Kedokteran, Fakultas Perikanan, Fakultas Teknik, FISIP, Fakultas Ekonomi, Fakultas Hukum, Fakultas Sastra, Fakultas Pertanian, Fakultas Peternakan, FMIPA dan Fakultas Kesehatan Masyarakat. Setiap sisi menyatakan jalan roda empat penghubung antar fakultas dan rektorat. Angka-angka yang terdapat pada setiap sisi merupakan bobot graf yang mewakili panjang jalan dengan satuan meter. Jarak-jarak ini dapat dilihat pada Tabel 1.

Penentuan lintasan terpendek dari simpul awal FMIPA ke gedung rektorat dan setiap fakultas lain di Unsrat delakukan dengan bantuan pemrograman Pascal. Data yang dimasukkan adalah entri dari matriks ketetanggaan. Untuk elemen matriks yang bernilai $\infty$ dimasukkan dengan nilai "99999". Hasil Perhitungan dapat dilihat pada Tabel 2.
Tabel 2. Lintasan Terpendek dari Simpul Awal Fakultas MIPA

\begin{tabular}{|c|c|c|}
\hline Simpul tujuan & Lintasan & Jarak (meter) \\
\hline 1 & $11,2,1$ & 670 \\
\hline 2 & 11,2 & 420 \\
\hline 3 & $11,2,1,3$ & 870 \\
\hline 4 & $11,2,1,3,4$ & 1020 \\
\hline 5 & $11,12,8,5$ & 1150 \\
\hline 6 & $11,12,8,5,6$ & 1250 \\
\hline 7 & $11,12,8,7$ & 1010 \\
\hline 8 & $11,12,8$ & 900 \\
\hline 9 & 11,9 & 310 \\
\hline 10 & $11,2,1,10$ & 870 \\
\hline 12 & 11,12 & 450 \\
\hline
\end{tabular}


Tabel 1. Matriks Ketetanggaan Untuk Graf Universitas Sam Ratulangi Manado

\begin{tabular}{|c|c|c|c|c|c|c|c|c|c|c|c|c|}
\hline & 1 & 2 & 3 & 4 & 5 & 6 & 7 & 8 & 9 & 10 & 11 & 12 \\
\hline 1 & 0 & 250 & 200 & $\infty$ & $\infty$ & $\infty$ & $\infty$ & $\infty$ & $\infty$ & 200 & $\infty$ & $\infty$ \\
\hline 2 & 250 & 0 & $\infty$ & $\infty$ & $\infty$ & $\infty$ & $\infty$ & $\infty$ & 520 & $\infty$ & 420 & 440 \\
\hline 3 & 200 & $\infty$ & 0 & 150 & $\infty$ & $\infty$ & $\infty$ & $\infty$ & $\infty$ & $\infty$ & $\infty$ & $\infty$ \\
\hline 4 & $\infty$ & $\infty$ & 150 & 0 & $\infty$ & $\infty$ & 350 & $\infty$ & $\infty$ & $\infty$ & $\infty$ & $\infty$ \\
\hline 5 & $\infty$ & $\infty$ & $\infty$ & $\infty$ & 0 & 100 & 150 & 250 & $\infty$ & $\infty$ & $\infty$ & $\infty$ \\
\hline 6 & $\infty$ & $\infty$ & $\infty$ & $\infty$ & 100 & 0 & $\infty$ & $\infty$ & $\infty$ & $\infty$ & $\infty$ & $\infty$ \\
\hline 7 & $\infty$ & $\infty$ & $\infty$ & 350 & 150 & $\infty$ & 0 & 110 & $\infty$ & $\infty$ & $\infty$ & 620 \\
\hline 8 & $\infty$ & $\infty$ & $\infty$ & $\infty$ & 250 & $\infty$ & 110 & 0 & $\infty$ & $\infty$ & $\infty$ & 450 \\
\hline 9 & $\infty$ & 520 & $\infty$ & $\infty$ & $\infty$ & $\infty$ & $\infty$ & $\infty$ & 0 & 610 & 310 & 740 \\
\hline 10 & 200 & $\infty$ & $\infty$ & $\infty$ & $\infty$ & $\infty$ & $\infty$ & $\infty$ & 610 & 0 & $\infty$ & $\infty$ \\
\hline 11 & $\infty$ & 420 & $\infty$ & $\infty$ & $\infty$ & $\infty$ & $\infty$ & $\infty$ & 310 & $\infty$ & 0 & 450 \\
\hline 12 & $\infty$ & 440 & $\infty$ & $\infty$ & $\infty$ & $\infty$ & 620 & 450 & 740 & $\infty$ & 450 & 0 \\
\hline
\end{tabular}

Berdasarkan tabel 2 dapat dilihat bahwa simpul yang dapat diakses langsung adalah simpul 2, 9 dan simpul 12 dengan jarak masing-masing 420, 310 dan 450 meter. Melalui perantara simpul 2 dapat diakses simpul 1 dengan jarak 670 meter yang menjadi perantara untuk mengakses simpul 3 dan 10 dengan jarak 870 meter, sedangkan melalui simpul 12 dapat diakses simpul 8 dengan jarak 900 meter yang menghubungkan lintasan ke simpul 5 dan 7 dengan jarak masing-masing 1150 dan 1010 meter, kemudian melalui simpul 5 lintasan terhubung dengan simpul 6 dengan jarak 1250 meter.

\section{KESIMPULAN DAN SARAN}

Berdasarkan hasil penelitian diperoleh bahwa lintasan terpendek dari FMIPA ke rektorat adalah melaui F. Kedokteran dengan jarak 670 meter yang selanjutnya dapat dilanjutkan ke F. Perikanan dan F. Peternakan dengan jarak masing-masing $870 \mathrm{~m}$. Melalui FKM dapat diakses Fakultas Sastra dengan jarak $900 \mathrm{~m}$. Fakultas Teknik dapat diakses melaui F. Perikanan dengan jarak $1020 \mathrm{~m}$ sedangkan F. Ekonomi dan ISIP diakses melalui F. Sastra dengan jarak masing-masing $1250 \mathrm{~m}$ dan $1150 \mathrm{~m}$. Fakultas Hukum diakses melalui F. Sastra dengan jarak 1010 m.

\section{DAFTAR PUSTAKA}

Ahuja, R.K., T.L. Magnanti, J.B. Orlin. 1993. Network Flow: Theory, Algorithms and Applications. Prentice Hall, New Jersey.

Google Map. 2010. Peta Universitas Sam Ratulangi Manado.

Munir, R. 2008. Matematika Diskrit. Penerbit Informatika. Bandung

Pradhana, B.A. 2009. Studi Dan Implementasi Persoalan Lintasan Terpendek Suatu Graf Dengan Algoritma Dijkstra Dan Algoritma Bellman-Ford.

http://www.informatika.org/ rinaldi/Matdis/2 006-2007/Makalah/Makalah060726.pdf [1 Februari_2011].

Sarwoko, E. A. 2003. Perancangan Arsitektur Pemaralelan untuk mencari Shortest Path dengan Algoritma Djikstra. Jurnal Matematika dan Komputer. 6: 137-143. 